\title{
ПРИМЕНЕНИЕ КЛАССИЧЕСКИХ МЕТОДОВ ДЛЯ ИЗОЛИРОВАНИЯ 2-МЕТОКСИГИДРОКСИБЕНЗОЛА (ГВАЯКОЛА) ИЗ БИОЛОГИЧЕСКОГО МАТЕРИАЛА
}

\author{
С Останин М.А. ${ }^{1}$ Чернова А.П. ${ }^{2}$, Шорманов В.К. ${ }^{1}$, Елизарова М.К. ${ }^{3}$ \\ ${ }^{1}$ Курский государственный медицинский университет (КГМУ) \\ Россия, 305041, Курская область, г. Курск, ул. К. Маркса, д. 3 \\ ${ }^{2}$ Институт природных ресурсов Томского политехнического университета (ИПР ТПУ) \\ Россия, 634050, Томская область, г. Томск, проспект Ленина, д. 30 \\ ${ }^{3}$ Ейский медицинский колледж (ЕМК), \\ Россия, 353680, Краснодарский край, г. Ейск, ул. Красная, д. 74/2
}

\begin{abstract}
Цель исследования - изучение особенностей изолирования гваякола из биологического материала классическими методами.

Материалы и методы. Объект исследования - 2-метоксигидроксибензол (гваякол) (фирма «Fluka»), содержащий $\geq 98 \%$ основного вещества. Модели биологических матриц для приготовления искусственных смесей с гваяколом - ткани печени и почек. В качестве основного метода очистки рассмотрена жидкость-жидкостная экстракция. Для идентификации применены ТСХ, УФ-спектрофотометрия и ВЭЖХ. Оценка количественного содержания 2-метоксигидроксибензола в извлечениях проводилась методом УФ-спектрофотометрии.

Результаты. Проведены исследования по сравнительному изолированию 2-метоксигидроксибензола (гваякола) из биологического материала рядом классических методов: Стаса-Отто, А.А. Васильевой, В.Ф. Крамаренко и П. Валова. Для идентификации изолируемого аналита использовали методы ТСХ, УФ-спектрофотометрии и ВЭЖХ. Количественную оценку выделяемого соединения проводили методом спектрофотометрии в УФ-области (аналитическая длина волны 277 нм). Предложен модифицированный вариант метода А.А. Васильевой, предусматривающий дополнительный этап экстракционной очистки выделяемого аналита, включающий переведение гваякола в виде ионизированной формы из хлороформного экстракта в водно-щелочной раствор (рН 12,5-13), подкисление водно-щелочного извлечения хлороводородной кислотой до $\mathrm{pH}$ 2-3 и экстракцию образовавшейся молекулярной формы гваякола в слой этилацетата.
\end{abstract}

Заключение. На основе предложенной модификации метода А.А. Васильевой разработана методика определения гваякола в тканях трупных органов. При содержании в биоматериале 0,01-0,2\% гваякола методика позволяет определять $(33,99-34,62) \pm(5,84-7,35) \%$ анализируемого вещества в тканях печени и $(34,87-35,73) \pm(5,66-6,97) \%-$ в тканях почек.

Ключевые слова: 2-метоксигидроксибензол (гваякол), классические методы изолирования на основе настаивания, модификация метода А.А. Васильевой, экстракционная очистка аналита, идентификация и количественное определение в биоматериале, химико-токсикологический анализ.

Останин Максим Александрович - заочный аспирант кафедры фармацевтической, токсикологической и аналитической химии, КГМУ, г. Курск. ORCID iD: 0000-0003-1984-5663. E-mail: m.a.ostanin@mail.ru

Чернова Анна Павловна - канд. хим. наук, доцент кафедры физической и аналитической химии, ИПР ТПУ, г. Томск. ORCID iD: 0000-0001-7002-492X. E-mail: apa2004@mail.ru

Шорманов Владимир Камбулатович - д-р. фарм. наук, профессор кафедры фармацевтической, токсикологической и аналитической химии, КГMУ, г. Курск. ORCID iD: 0000-0001-8872-0691. E-mail: R-WLADIMIR@yandex.ru (автор, ответственный за переписку)

Елизарова Мадина Камбулатовна - канд. фарм. наук, преподаватель, ЕMК, г. Ейск. ORCID iD: 0000-0002-8944-4358. E-mail: goukkemk@mail.ru

2-метоксигидроксибензол (в дальнейшем гваякол) (синонимы: 1-гидрокси-2-метоксибензол, 2-метоксифенол, 2-гидроксианизол, ортогидроксианизол) - это биологически активное соединение, которое применяется в медицине как мягкое анестезирующее, антисептическое и отхаркивающее средство, является компонентом пломбировочных стоматологических материалов $[4,14,16]$.

В ветеринарии гваякол используется при хронических воспалительных процессах дыхательных путей и гастроэнтеритах [16].

Данное соединение также является полупродуктом ряда синтезов душистых и лекар- ственных средств и обладает способностью ингибировать термическую полимеризацию стирола [8].

Структурная формула гваякола имеет следующий вид:<smiles>COc1ccccc1O</smiles>

Его брутто-формула - $\mathrm{C}_{7} \mathrm{H}_{8} \mathrm{O}_{2}$, молярная масca $-124,13$ a.e.M. 
Гваякол представляет собой бесцветные кристаллы, темнеющие на воздухе и на свету, или бесцветную с кремоватым оттенком жидкость с сильным своеобразным ароматическим запахом и жгучим вкусом. Он ограниченно растворим в воде (до $1,7 \%$ при $17^{\circ} \mathrm{C}$ ), значительно лучше в таких растворителях как алканолы, трихлорметан, диэтиловый эфир, ледяная уксусная кислота, водные растворы щелочей. Гваякол плавится в интервале температур $27-29^{\circ} \mathrm{C}$, кипит по достижении $200-205^{\circ} \mathrm{C}[1,4,6,13,15]$.

Вещество в значительной степени токсично для теплокровных. $\mathrm{LD}_{50}$ гваякола (мг/кг) при внутрижелудочном введении крысам составляет 520, мышам - 621, при ингаляционном введении мышам - 7570, при перкутанном введении кроликам - $4600[2,3,15]$.

В мировой научной литературе приводится целый ряд случаев летальных отравлений гваяколом, вызванных употреблением как самого вещества, так и содержащих его препаратов и фенольных смесей $[5,11,12,14,15]$.

Все это характеризует данное соединение как потенциальный объект судебно-химического исследования.

Важным этапом пробоподготовки в процессе судебно-химического исследования принято считать изолирование аналита из биологических матриц.

До настоящего времени вопросы, связанные с изолированием гваякола из биологического материала, остаются недостаточно разработанными.

Для извлечения из биоматриц соединений из группы алкил- и метоксипроизводных гидроксибензола, к которым относится и гваякол, возможно применение способов настаивания с водными и органическими жидкостям $[7,10]$.

Часто хорошие результаты изолирования достигаются при использовании так называемых классических методов, основанных на принципе настаивания с водными растворами кислой и щелочной реакции, а также с подкисленным этанолом.

Цель исследования - изучение особенностей изолирования гваякола из биологического материала классическими методами.

\section{МАТЕРИАЛЫ И МЕТОДЫ ИССЛЕДОВАНИЯ}

Химический объект проведенного исследования - 2-метоксигидроксибензол (гваякол) (фирма «Fluka»), содержащий $\geq 98 \%$ основного вещества.

Моделями биологических матриц для приготовления искусственных смесей, содержащих гваякол, явились ткани печени и почек коровы, полученные после забоя животного на продажу и находящиеся до начала эксперимента в состоянии заморозки при $0-2^{\circ} \mathrm{C}$.

Приготовленные для исследования сравнительного изолирования биологические объекты представляли собой искусственные смеси частиц печени размерами $2 * 10^{-3}-5 * 10^{-3}$ м с аналитом, содержание которого в искусственных смесях устанавливалось на уровне $0,1 \%$. Смеси выдерживали 45 мин при $18-22^{\circ} \mathrm{C}$.

Аналит изолировали из биоматрицы четырьмя методами, считающимися классическими: Стаса-Отто (этанолом, подкисленным щавелевой кислотой), А.А. Васильевой (водой, подкисленной щавелевой кислотой, В.Ф. Крамаренко (водой, подкисленной серной кислотой) и П. Валова (водой, подщелоченной гидроксидом натрия).

\section{1. Изолирование по Cтасу-Oтmо.}

Искусственную смесь частиц печени с гваяколом массой 25 г настаивали трижды (каждый раз в течение часа 24 часа) с порциями $95 \%$ этанола по 25 мл каждая в условиях подкисления смеси щавелевой кислотой для поддержания $\mathrm{pH}$ на уровне 2,5-3,0. Отдельные извлечения, получаемые декантацией, сливали в одну выпарительную чашку, упаривали на водяной бане до густоты сиропа при температуре $36-38^{\circ} \mathrm{C}$ и проводили очистку, осаждая балластные вещества в полученном концентрате путем добавления по каплям этанола. Осадок отфильтровывали, фильтрат сгущали до густоты сиропа и вновь проводили осаждение балластных веществ по вышеописанной схеме. Стадию очистки считали завершенной, если фиксировалось отсутствие выпадения осадка от прибавления первых капель этанола к полученному в очередной раз сиропообразному концентрату. В этом случае концентрат разбавляли 10 мл воды и экстрагировали аналит из полученного кисло-водного раствора трехкратно порциями хлороформа по 10 мл каждая. Хлороформные экстракты объединяли, обезвоживали, пропуская через три слоя фильтровальной бумаги, вносили в выпарительную чашку, упаривали до объема 4-6 мл, количественно переносили в мерную колбу на 10 мл и доводили до метки хлороформом (раствор для исследования).

\section{2. Изолирование по А.А. Васильевой.}

Искусственную смесь частиц печени с гваяколом массой 25 г настаивали дважды (последовательно в течение 2 часов и 1 часа) с порциями воды по 50 мл каждая в условиях подкисления смеси щавелевой кислотой для поддержания $\mathrm{pH}$ на уровне 2,0-2,5. Отдельные извлечения, получаемые декантацией, смешивали, фильтровали через три слоя марли и экстрагировали аналит из полученного кисло-водного фильтрата трех- 
кратно порциями хлороформа по 10 мл каждая. Хлороформные экстракты объединяли, обезвоживали и далее поступали так же как описано выше для изолирования по Стасу-Отто, получая раствор для исследования.

\section{3. Изолирование по В.Ф. Крамаренко.}

Искусственную смесь частиц печени с гваяколом массой 25 г настаивали трижды (первый раз в течение 2 часов, два последующих раза по 1 часу) с порциями воды по 25 мл каждая в условиях подкисления смеси серной кислотой для поддержания $\mathrm{pH}$ на уровне 2,5. Отдельные извлечения, получаемые декантацией, смешивали, центрифугировали, центрифугат отделяли, насыщали сульфатом аммония, выпадающий осадок отделяли центрифугированием. Центрифугат сливали с осадка, аналит экстрагировали из кисло-водного центрифугата трехкратно порциями хлороформа по 10 мл каждая. Хлороформные экстракты объединяли, обезвоживали и далее поступали так же как описано выше для изолирования по Стасу-Отто, получая раствор для исследования.

\section{4. Изолирование по П. Валову.}

Искусственную смесь частиц печени с гваяколом массой 25 г настаивали однократно (в течение 0,5 часа) с порцией воды объемом 25 мл в условиях подщелачивания смеси гидроксидом натрия для поддержания $\mathrm{pH}$ на уровне 12-13 (концентрация гидроксида натрия в водном растворе примерно 1\%). Водно-щелочное извлечение, получаемое декантацией, центрифугировали, центрифугат отделяли, обрабатывали 30 мл 10\% раствора вольфрамата натрия в условиях подкисления $10 \%$ раствором серной кислоты до $\mathrm{pH} 2$ при кипячении в течение 0,3 часа, выпадающий осадок отделяли центрифугированием. Центрифугат сливали с осадка, аналит экстрагировали из кисло-водного центрифугата порцией диэтилового эфира объемом 10 мл, органический экстракт отделяли, аналит экстрагировали из него в виде солевой формы 10 мл 10\% раствора гидроксида натрия, воднощелочной экстракт отделяли, подкисляли $25 \%$ раствором серной кислоты до $\mathrm{pH} 2$ и экстрагировали аналит в молекулярной форме 10 мл диэтилового эфира. Эфирный экстракт обезвоживали и далее поступали так же как описано выше для изолирования по Стасу-Отто, получая раствор для исследования.

После изолирования по каждому из рассмотренных классических методов в две выпарительные чашки помещали по 2,5 мл раствора для исследования, после чего растворитель из чашек испаряли.

Остаток в чашке № 1 растворяли в 5 мл этанола. Остаток из 0,3 мл полученного раствора хроматографировали в тонком слое силикагеля (пластины «Сорбфил» ПТСХ-АФ-А-УФ, подвижная фаза - хлороформ-бензол (9:1)). Хроматограммы проявляли, облучая их светом с длиной волны 254 нм.

Аналит идентифицировали по величине абсолютной хроматографической подвижности. Исследуемое вещество извлекали из хроматограммы 5 мл этанола и идентифицировали по характеру поглощения этанольного извлечения в области кварцевого ультрафиолета.

Фиксируемая в области длинноволнового максимума оптическая плотность служила основой для расчета количественного содержания аналита с использованием уравнения градуировочного графика: $\mathrm{A}=0,02078 \cdot \mathrm{C}+0,04332$.

Остаток в чашке № 2 растворяли в 3-4 мл ацетонитрила, количественно переносили образующийся раствор в мерную колбу на 5 мл и доводили до метки этим же растворителем. 1 мл полученного раствора переносили в мерную колбу вместимостью 10 мл, туда же прибавляли 4 мл ацетонитрила и доводили содержимое колбы до метки ацетатным буферным раствором с $\mathrm{pH}=5,5\left(0,04 \mathrm{M} \mathrm{CH} \mathrm{COONH}_{4}, \mathrm{CH}_{3} \mathrm{COOH}\right)(\mathrm{pac}-$

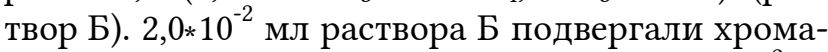
тографированию в колонке высотой $2,5 * 10^{-2}$ и диаметром $3,9 * 10^{-3}$ м с сорбентом «Discovery ${ }^{\circledR}$ С18», термостатируемой при $40^{\circ} \mathrm{C}$, используя прибор «LC-20 Prominance» (фирма Shimadzu, Япония) с матричным фотодиодным детектором и элюируя смесью ацетонитрил-ацетатный буферный раствор с $\mathrm{pH}=5,5\left(0,04 \mathrm{M} \mathrm{CH} \mathrm{COONH}_{4}\right.$, $\left.\mathrm{CH}_{3} \mathrm{COOH}\right)$ (5:5 по объему) со скоростью 1 мл/мин. Длина волны для регистрации оптической плотности - 280 нм.

Аналит идентифицировали по времени удерживания [9].

\section{РЕЗУЛЬТАТЫ ИССЛЕДОВАНИЯ И ИХ ОБСУЖДЕНИЕ}

Рассчитанные в процессе идентификации значения абсолютной хроматографической подвижности извлеченного из биоматрицы аналита (метод ТСХ) после его изолирования по каждому из рассмотренных способов и проведения первичной очистки колебались в интервале 0,61-0,63, что совпадало со значением абсолютной хроматографической подвижности вещества-стандарта $(0,61 \pm 0,02)$.

При оценке идентичности анализируемого соединения гваяколу методом спектрофотометрии обнаруживалось совпадение формы УФспектральной кривой аналита и положения на ней точек экстремумов (223-225 нм и 277-278 нм) с этими же характеристиками веществастандарта $\left(\lambda_{\max 1}=225 \pm 2 \mathrm{HM} ; \lambda_{\max 2}=277 \pm 2 \mathrm{HM}\right)$. 
Оптические характеристики стандарта гваякола и гваякола, извлеченного из биологического материала классическими методами (поглощение в среде этанола) (n=6)

Optical characteristics of standard guaiacol and guaiacol extracted from biological material by classical methods (absorption in ethanol) $(\mathrm{n}=6)$

\begin{tabular}{|c|c|c|c|c|c|}
\hline \multirow[b]{2}{*}{$\begin{array}{c}\text { Оптические } \\
\text { xарактеристики } \\
\text { Optical characteristics }\end{array}$} & \multirow[b]{2}{*}{$\begin{array}{c}\text { Стандарт } \\
\text { гваякола } \\
\text { Guaiacol } \\
\text { standard }\end{array}$} & \multicolumn{4}{|c|}{$\begin{array}{c}\text { Гваякол, изолированный из биоматериала } \\
\text { Guaiacol, isolated from biomaterial }\end{array}$} \\
\hline & & $\begin{array}{c}\text { по методу } \\
\text { Стаса-Отто } \\
\text { according } \\
\text { to the Stas-Otto's } \\
\text { method } \\
\end{array}$ & $\begin{array}{c}\text { по методу } \\
\text { A.А. Васильевой } \\
\text { according } \\
\text { to the method } \\
\text { of A.A. Vasilyeva } \\
\end{array}$ & $\begin{array}{c}\text { по методу } \\
\text { В.Ф. Крамаренко } \\
\text { according } \\
\text { to the method } \\
\text { of V.F. Kramarenko }\end{array}$ & $\begin{array}{l}\text { по методу } \\
\text { П. Валова } \\
\text { according } \\
\text { to the method } \\
\text { of P. Valov }\end{array}$ \\
\hline \multicolumn{6}{|c|}{ Кротковолновая полоса поглощения } \\
\hline $\begin{array}{c}\lambda_{\max 1, \mathrm{HM}} \\
\lambda_{\max 1, \mathrm{~nm}}\end{array}$ & 225 & 226 & 225 & 225 & 225 \\
\hline $\begin{array}{l}\mathrm{E}^{1 \% / 1} / 1 \mathrm{~cm} \\
\mathrm{E}^{1 \% / 1 \mathrm{~cm}}\end{array}$ & 301 & - & - & - & - \\
\hline$\varepsilon$ & 4754 & - & - & - & - \\
\hline $\begin{array}{c}\Delta \mathrm{E}, \text { кКал/моль } \\
\Delta \mathrm{E}, \mathrm{kcal} / \mathrm{mol}\end{array}$ & 124.4 & 123.9 & 124.4 & 124.4 & 124.4 \\
\hline \multicolumn{6}{|c|}{ Длинноволновая полоса поглощения } \\
\hline \multicolumn{6}{|c|}{ Long wavelength absorption band } \\
\hline $\begin{array}{c}\lambda_{\max 2, \mathrm{HM}} \\
\lambda_{\max 2,}, \mathrm{~nm}\end{array}$ & 277 & 277 & 278 & 277 & 277 \\
\hline $\begin{array}{l}\mathrm{E}^{1 \%} / 1 \mathrm{~cm} \\
\mathrm{E}^{1 \%} / 1 \mathrm{~cm}\end{array}$ & 214 & - & - & - & - \\
\hline$\varepsilon$ & 3376 & - & - & - & - \\
\hline $\begin{array}{c}\Delta \mathrm{E}, \text { кКал/моль } \\
\Delta \mathrm{E}, \mathrm{kcal} / \mathrm{mol}\end{array}$ & 101.1 & 101.1 & 100.7 & 101.1 & 101.1 \\
\hline
\end{tabular}

Качественная оценка изолированного и очищенного аналита методом ВЭЖХ показала, что продолжительность нахождения его в колонке неподвижной фазы «Discovery ${ }^{\circledR} \mathrm{C} 18$ » колебалась в заданных условиях от 4,255 до 4,270. Данные результаты соответствовали времени удерживания стандарта гваякола $(4,261 \pm 0,010)$ в этой же колонке.

Результаты оценки количественного содержания гваякола в извлечениях из модельных смесей с тканью печени после изолирования рассмотренным рядом классических методов представлены в табл. 2.

Содержание табл. 2 позволяет заключить, что степень извлечения гваякола из биоматериала рассмотренными классическими методами увеличивается в ряду: метод Стаса-Отто < метод В.Ф. Крамаренко < П. Валова < А.А. Васильевой.

Таким образом, наибольшую степень извлечения аналита из биоматрицы $(37,01 \pm 4,85 \%)$ удавалось достичь, применяя классический метод А.А. Васильевой. Рассчитанные для данного метода значения предела обнаружения и предела количественного определения с использовани- ем УФ-спектрофотометрии составили соответственно 5 и 10 мг в 100 г биологического объекта (ткань печени). Основываясь на подобных результатах, метод А.А. Васильевой был выбран нами в дальнейшем в качестве основы для разработки методики определения гваякола в биологическом материале.

Нами была проведена модификация метода А.А. Васильевой, заключающаяся в усовершенствовании этапа очистки извлекаемого из биоматрицы гваякола. При этом по сравнению с классическим вариантом модифицированный вариант после экстракции хлороформом аналита из объединенного кисло-водного извлечения предусматривал переведение гваякола в виде солевой формы из хлороформного экстракта в водно-щелочной раствор ( $\mathrm{pH}$ 12,5-13), последующее подкисление водно-щелочного извлечения хлороводородной кислотой до $\mathrm{pH}$ 2-3 и экстракцию образовавшейся при этом молекулярной формы гваякола в слой этилацетата.

Модифицированный вариант был применен для определения различных количеств гваякола в тканях внутренних органов (печени и почек). 
Результаты оценки количественного содержания гваякола в извлечениях из модельных смесей с тканью печени

The results of evaluating the quantitative content of guaiacol in extracts from model mixtures with liver tissue

\begin{tabular}{|c|c|c|c|c|c|}
\hline \multirow{2}{*}{ № } & \multirow{2}{*}{$\begin{array}{c}\text { Классический метод } \\
\text { изолирования } \\
\text { Classical method } \\
\text { of isolating according to }\end{array}$} & \multirow{2}{*}{$\begin{array}{c}\text { Введено гваякола, мг на } 25 \text { г } \\
\text { биологического объекта } \\
\text { Introduction of guaiacol, } \\
\text { mg per } 25 \mathrm{~g} \text { of biological object }\end{array}$} & \multicolumn{2}{|c|}{$\begin{array}{l}\text { Найдено } \\
\text { Found }\end{array}$} & \multirow{2}{*}{$\begin{array}{c}\text { Метрологические } \\
\text { храктеристики } \\
\text { Metrological specifications }\end{array}$} \\
\hline & & & $\begin{array}{l}\mathrm{M} \Gamma \\
\mathrm{mg}\end{array}$ & $\%$ & \\
\hline 1 & 2 & 3 & 4 & 5 & 6 \\
\hline 1 & $\begin{array}{c}\text { Стаса-Отто } \\
\text { Stas-Otto }\end{array}$ & $\begin{array}{l}0.02542 \\
0.02375 \\
0.02468 \\
0.02715 \\
0.02649\end{array}$ & $\begin{array}{l}0.007189 \\
0.005636 \\
0.004786 \\
0.007236 \\
0.004204\end{array}$ & $\begin{array}{l}28.28 \\
23.73 \\
19.39 \\
26.65 \\
15.87\end{array}$ & $\begin{array}{c}\bar{x}=22.78 \\
\mathrm{~S}=5.51 \\
\mathrm{~S}_{\bar{x}}=2.30 \\
\Delta \bar{x}=6.38 \\
\varepsilon=28.01\end{array}$ \\
\hline 2 & $\begin{array}{l}\text { A.А. Васильевой } \\
\text { А.A. Vasilyeva }\end{array}$ & $\begin{array}{l}0.02481 \\
0.02684 \\
0.02455 \\
0.02736 \\
0.02530\end{array}$ & $\begin{array}{l}0.008537 \\
0.008722 \\
0.007996 \\
0.011535 \\
0.010042\end{array}$ & $\begin{array}{l}34.41 \\
36.22 \\
32.57 \\
42.16 \\
39.69\end{array}$ & $\begin{array}{c}\bar{x}=37.01 \\
\mathrm{~S}=3.90 \\
\mathrm{~S}_{\bar{x}}=1.74 \\
\Delta \bar{x}=4.85 \\
\varepsilon=13.10\end{array}$ \\
\hline 3 & $\begin{array}{c}\text { В.Ф. Крамаренко } \\
\text { V.F. Kramarenko }\end{array}$ & $\begin{array}{l}0.02268 \\
0.03643 \\
0.02512 \\
0.02429 \\
0.02395\end{array}$ & $\begin{array}{l}0.008476 \\
0.007585 \\
0.007132 \\
0.005621 \\
0.007772\end{array}$ & $\begin{array}{l}27.37 \\
20.82 \\
28.39 \\
23.14 \\
32.45\end{array}$ & $\begin{array}{c}\bar{x}=26.43 \\
\mathrm{~S}=4.56 \\
\mathrm{~S}_{\bar{x}}=2.04 \\
\Delta \bar{x}=5.67 \\
\varepsilon=21.46\end{array}$ \\
\hline 4 & $\begin{array}{l}\text { П. Валова } \\
\text { Р. Valov }\end{array}$ & $\begin{array}{l}0.02431 \\
0.02716 \\
0.02523 \\
0.02362 \\
0.02568\end{array}$ & $\begin{array}{l}0.007906 \\
0.009501 \\
0.006853 \\
0.005742 \\
0.007779\end{array}$ & $\begin{array}{l}32.52 \\
34.98 \\
27.16 \\
24.31 \\
30.29 \\
\end{array}$ & $\begin{array}{c}\bar{x}=29.85 \\
\mathrm{~S}=4.23 \\
\mathrm{~S}_{\bar{x}}=1.89 \\
\Delta \bar{x}=5.26 \\
\varepsilon=17.62\end{array}$ \\
\hline
\end{tabular}

В целом, модифицированный вариант метода имел следующий вид.

Искусственную смесь биоматериала (мелкоизмельченной ткани печени или почек) с тем или иным количеством гваякола массой 25 г настаивали дважды (последовательно в течение 2 часов и 1 часа) с порциями воды по 50 мл каждая в условиях подкисления смеси щавелевой кислотой для поддержания $\mathrm{pH}$ на уровне 2,0-2,5. Извлечения, получаемые декантацией, смешивали, фильтровали через три слоя марли и экстрагировали аналит из полученного кисловодного фильтрата трехкратно порциями хлороформа по 10 мл каждая (продолжительность отдельного этапа экстрагирования - 4 мин). Хлороформные экстракты объединяли, обезвоживали, пропуская через три слоя фильтровальной бумаги, вносили в выпарительную чашку, упаривали до объема 4-6 мл, количественно переносили в мерную колбу на 10 мл и доводили до метки хлороформом. Хлороформный раствор встряхивали дважды с порциями 5\% раствора гидроксида натрия по 10 мл каждая при про- должительности отдельного этапа экстрагирования 4 минуты.

Водно-щелочные экстракты объединяли в делительной воронке, подкисляли содержимое воронки $24 \%$ раствором хлороводородной кислоты до рН 2-3 и проводили экстракцию получаемого кисло-водного раствора дважды порциями этилацетата по 20 мл. Этилацетатные экстракты объединяли, обезвоживали, пропуская через три слоя фильтровальной бумаги, вносили в выпарительную чашку, упаривали в токе воздуха комнатной температуры до объема 4-6 мл, количественно переносили в мерную колбу на 10 мл и доводили до метки этилацетатом (раствор для исследования). Далее поступали по вышеописанной схеме.

Отличия состояли в том, что после растворения остатка в чашке № 1 в 5 мл этанола хроматографированию (ТСХ) подвергали остаток из 0,6 мл полученного раствора, а после растворения остатка в чашке № 2 в 5 мл ацетонитрила в мерной колбе на 5 мл в мерную колбу вместимостью 10 мл переносили 2 мл полученного раствора. 


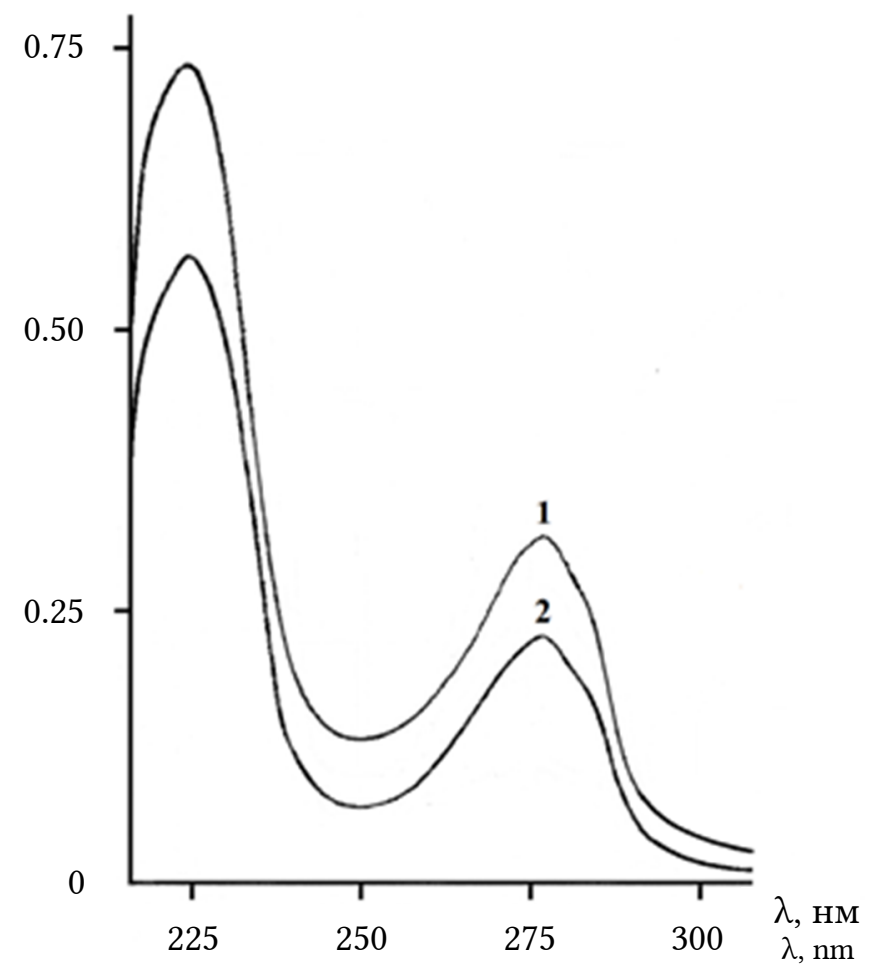

Рис. 1. УФ-спектры в 95\% этаноле: 1 - стандарта 2-метоксигидроксибензола (0,0025\%); 2 - 2-метоксигидроксибензола, извлеченного из ткани печени модифицированным методом А.А. Васильевой.

Fig. 1. UV spectra in 95\% ethanol: 1 - 2-methoxyhydroxybenzene standard (0.0025\%); 2 - 2-methoxyhydroxybenzene, extracted from the liver tissue by the modified method of A.A. Vasilyeva.

Интенсивность, усл. ед.

Intensity, conv. units

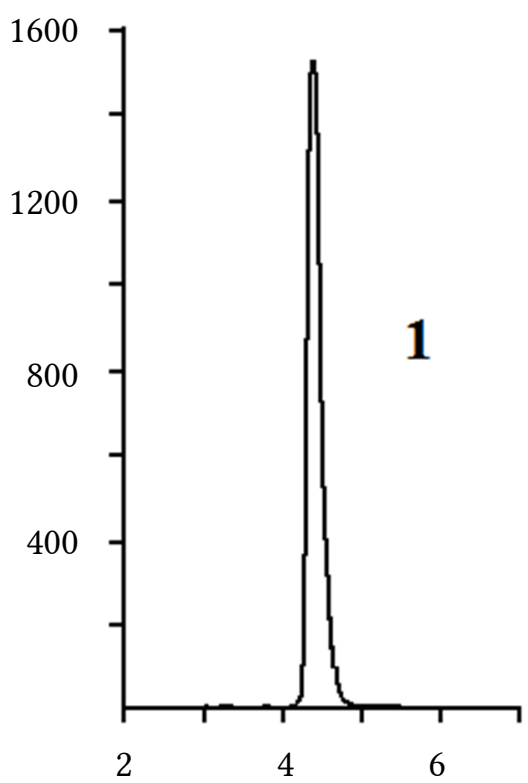

Время удерживания, мин Retention time, min
Интенсивность, усл. ед. Intensity, conv. units

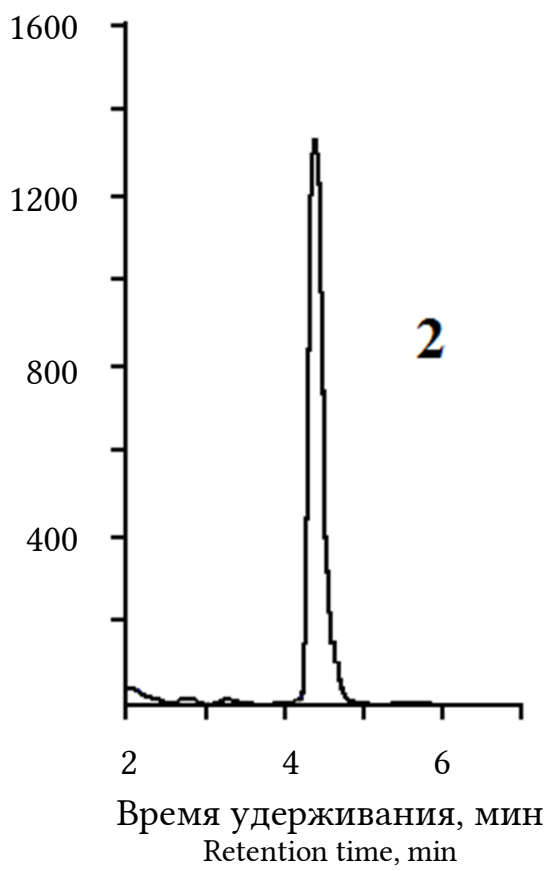

Рис. 2. Хроматограммы 2-метоксигидроксибензола, полученные методом ВЭЖХ: 1 - хроматограмма вещества-стандарта; 2 - хроматограмма вещества, извлеченного из ткани печени модифицированным методом А.А. Васильевой.

Fig. 2. Chromatogram of 2-methoxyhydroxybenzene, obtained by HPLC: 1 - chromatogram of the standard substance; 2 - chromatogram of a substance extracted from the liver tissue by the modified A.A. Vasilyeva's method. 
Результаты определения гваякола модифицированной методикой в модельных смесях с тканями печени и почек $(\mathrm{n}=5 ; \mathrm{P}=0.95)$

The results of the determination of guaiacol by the modified method in model mixtures with liver and kidney tissues $(\mathrm{n}=5 ; \mathrm{P}=0.95)$

\begin{tabular}{|c|c|c|c|c|c|c|}
\hline \multicolumn{2}{|c|}{$\begin{array}{c}\text { Внесено гваякола } \\
\text { в биологический объект } \\
\text { Incorporated guaiacol into a biological } \\
\text { object } \\
\end{array}$} & \multicolumn{5}{|c|}{$\begin{array}{c}\text { Найдено, \% }(\mathrm{n}=5, \mathrm{p}=0.95) \\
\text { Found, \% (n = 5, p = 0.95) }\end{array}$} \\
\hline $\begin{array}{l}\mathrm{M} \Gamma / 25 \mathrm{\Gamma} \\
\mathrm{mg} / 25 \mathrm{~g}\end{array}$ & $\%$ & $\bar{x}$ & S & $\mathrm{S}_{\mathrm{x}}$ & $\Delta \bar{x}$ & $\mathrm{~S}_{\mathrm{r}}, \%$ \\
\hline \multicolumn{7}{|c|}{ Исследование печени } \\
\hline \multicolumn{7}{|c|}{ Liver examination } \\
\hline 2.5 & 0.01 & 34.17 & 5.90 & 2.64 & 7.35 & 17.27 \\
\hline 5.0 & 0.02 & 34.53 & 5.46 & 2.44 & 6.79 & 15.81 \\
\hline 12.5 & 0.05 & 33.99 & 5.05 & 2.26 & 6.28 & 14.86 \\
\hline 25.00 & 0.1 & 34.31 & 4.86 & 2.18 & 6.04 & 14.17 \\
\hline 50.00 & 0.2 & 34.62 & 4.70 & 2.10 & 5.84 & 13.58 \\
\hline \multicolumn{7}{|c|}{ Исследование почек } \\
\hline \multicolumn{7}{|c|}{ Kidney examination } \\
\hline 2.5 & 0.01 & 34.87 & 5.61 & 2.51 & 6.97 & 16.08 \\
\hline 5.0 & 0.02 & 35.23 & 5.16 & 2.31 & 6.41 & 14.63 \\
\hline 12.5 & 0.05 & 35.65 & 4.88 & 2.18 & 6.07 & 13.70 \\
\hline 25.00 & 0.1 & 35.42 & 4.70 & 2.11 & 5.84 & 13.26 \\
\hline 50.00 & 0.2 & 35.73 & 4.55 & 2.04 & 5.66 & 12.74 \\
\hline
\end{tabular}

УФ-спектр 2-метоксигидроксибензола (гваякола), изолированного из ткани печени и очищенного в соответствии с методикой, разработанной на основе модификации метода А.А. Васильевой, в сравнении с УФ-спектром веществастандарта представлен на рис. 1.

Как свидетельствуют полученные результаты, обнаруживается практическое совпадение формы спектральных кривых и положения точек экстремумов (максимумов) на представленных спектрах.

Хроматограммы (ВЭЖХ) 2-метоксигидроксибензола (гваякола), выделенного из ткани печени и прошедшего процедуру очистки в соответствии с разработанной методикой на основе предложенной модификации метода А.А. Васильевой, а также стандарта данного соединения представлены на рис. 2.

Как свидетельствуют полученные результаты, значения времени удерживания гваякола, извлеченного из биоматрицы, и стандарта этого же соединения практически совпадают. Вместе с тем, при рассмотрении области значений времени удерживания от 4 до 5 мин на хроматограмме исследуемого соединения в сравнении с хроматограммой вещества-стандарта не обнаруживаются дополнительные пики и значимое смещение базовой линии.

Результаты определения гваякола модифицированной методикой в модельных смесях с тканью печени и почек при содержании анали- та в биоматрицах от 0,01 до $0,2 \%$ представлены в табл. 3.

Как видно, в результате усложнения схемы очистки снижалась степень извлечения аналита на 3-4\%. Однако при этом удавалось повысить пределы обнаружения (до 2,5 мг в 100 г тканей печени и до 2 мг в 100 г тканей почек) и определения (до 5 мг в 100 г тканей печени и до 4 мг в 100 г тканей почек) вследствие уменьшения в итоговом этилацетатном экстракте количества соэкстрагирующихся веществ биоматрицы.

Совокупность проведенных исследований определяет возможность сделать следующие выводы:

1. Изучены особенности изолирования гваякола из биологического материала (режим настаивания) рядом классических методов (Стаса-Отто, А.А. Васильевой, В.Ф. Крамаренко и П. Валова).

Степень извлечения аналита указанными методами колеблется от 22,78 $6,38 \%$ (по методу Стаса-Отто) до $37,01 \pm 4,85 \%$ (по методу А.А. Васильевой).

2. Для изолирования гваякола из тканей органов предложена модификация метода А.А. Васильевой, отличающаяся от классического варианта переведением гваякола в ионизированном виде из хлороформного экстракта в водно-щелочной раствор с $\mathrm{pH}$ 12,5-13, подкислением последнего хлороводородной кислотой и 
экстракцией молекулярной формы гваякола в слой этилацетата.

3. На основе предложенного модифицированного варианта разработана методика определения гваякола в тканях трупных органов (печень и почки).

При содержании 0,01-0,2\% гваякола в биоматрице методика позволяет определить до $34,62 \%$ аналита в модельных смесях с тканями печени (открываемый минимум 2,5 мг в 100 г биоматрицы) и до $35,73 \%$ в модельных смесях с тканями почек (открываемый минимум 2 мг в 100 г биоматрицы).

Разработанная методика может быть применена в практике судебно-химического анализа при экспертизе случаев летального отравления 2-метоксигидроксибензолом (гваяколом).

\section{КОНФЛИКТ ИНТЕРЕСОВ}

Авторы декларируют отсутствие явных и потенциальных конфликтов интересов, связанных с публикацией настоящей статьи.

\section{ИСТОЧНИКИ ФИНАНСИРОВАНИЯ} ния.

Авторы заявляют об отсутствии финансирова-

\section{СООТВЕТСТВИЕ ПРИНЦИПАМ ЭТИКИ}

Протокол исследования был одобрен региональным этическим комитетом Курского государственного медицинского университета от 20.04.2018 г., протокол № 4.

\section{ЛИТЕРАTУРA/REFERENCES}

1. Асташкина А.П., Шорманов В.К., Останин М.А., Гришечко О.И., Елизарова М.К. Особенности распределения 2- и 3- метоксипроизводных гидроксибензола в организме теплокровных животных. Фармация. 2013; 5:5-8 [Astashkina A.P., Shormanov V.K., Ostanin M.A., Grishechko O.I., Elizarova M.K. Distribution of hydroxybenzene methoxy derivatives in warmblooded animals. Farmatsiya. 2013; 5:5-8. (in Russ.)]

2. Грушко Я.М. Вредные органические соединения в промышленных сточных водах. Ленинград: Химия, 1982. 216 с. [Grushko Ya.M. Harmful organic compounds in industrial wastewater. Leningrad: Khimiya, 1982. 216 p. (in Russ.)]

3. Измеров Н.Ф., Саноцкий И.В., Сидоров К.К. Параметры токсикометрии промышленных ядов при однократном воздействии. Москва: Медицина, 1977. 240 c. [Izmerov N.F., Sanotskiy I.V., Sidorov K.K. Parameters of toxicometry of industrial poisons at single exposure. Moscow: Meditsina, 1977. 240 p. (in Russ.)]

4. Краткая химическая энциклопедия. Под ред. Кнунянца И.Л. Том 5. Москва: Советская энциклопедия, 1967. 812 с. [A brief chemical encyclopedia. I.L. Knunyants, editor. Moscow: Sovetskaya entsiklopediya, 1967. 812 p. (in Russ.)]
5. Могош Г. Острые отравления: диагноз, лечение. Бухарест: Медицинское издательство, 1984. 580 с. [Mogosh G. Acute poisoning: diagnosis, treatment. Bucharest: Meditsinskoye izdatel'stvo, 1984. 580 p. (in Russ.)]

6. Пассет Б.В., Воробьева В.Я. Технология химикофармацевтических препаратов и антибиотиков. Москва: Медицина, 1977. 430 с. [Passet B.V., Vorob'yeva V.Ya. Technology of chemical and pharmaceutical preparations and antibiotics. Moscow: Meditsina, 1977. 430 p. (in Russ.)]

7. Пугачёва О.И., Асташкина А.П., Шорманов В.К., Останин М.А. Особенности распределения 2,4- и 2,6-диметильных производных гидроксибензола в организме теплокровных животных. Судебномедицинская экспертиза. 2014; 57(4):44-48 [Pugacheva O.I., Astashkina A.P., Shormanov V.K., Ostanin M.A. Specific features of the distribution of 2,4- and 2,6-dimethyl derivatives of hydroxybenzene in the body of the warm-blooded animals. Sudebnomeditsinskaya ekspertiza. 2014; 57(4):44-48 (in Russ.)]

8. Шалыминова Д.П., Черезова Е.Н., Пономарев А.В., Тананаев И.Г. Фенольные продукты радиационно-термического разложения лигнина как ингибиторы термополимеризации стирола. Химия вbсоких энергий. 2008; 42(5):388-392. [Shalyminova D.P., Cherezova E.N., Ponomarev A.V., Tananaev I.G. Phenolic products of radiation-thermal degradation of lignin as inhibitors for thermal polymerization of styrene. High Energy Chemistry. 2008; 42(5):342-345] DOI: 10.1134/S0018143908050020

9. Шорманов В.К., Иванов В.П., Королев В.А., Маслов С.В., Жуков Д.А., Олимпиев И.Б., Олейник С.М. Судебно-химическое определение фурадана. Судебно-медицинская экспертиза. 2005; 48(3):27-31 [Shormanov V.K., Ivanov V.P., Korolev V.A., Maslov S.V., Zhukov D.A., Olimpiyev I.B., Oleynik S.M. Forensic chemical definition of furadan. Sudebno-meditsinskaya ekspertiza. 2005; 48(3):27-31 (in Russ.)]

10. Шорманов В.К., Пугачёва О.И., Асташкина А.П., Цацуа Е.П. Особенности распределения 2,6-дитрет-бутил-4-метилгидроксибензола в организме теплокровных животных. Судебно-медицинская экспертиза. 2016; 59(1): 29-34 [Shormanov V.K., Pugacheva O.I., Astashkina A.P., Tsatsua E.P. Features of the distribution of 2,6-di-tert-butyl-4metilgidroksibenzoat in the body of warm-blooded animals. Sudebno-meditsinskaya ekspertiza. 2016; 59(1): 29-34 (in Russ.)]

11. Amstutz H.E. Suspected pentachlorophenol and creosote poisoning. Mod Vet Pract. 1980; 61(1):53-54.

12. Bowman C.E., Muhleman M.F., Walters E. A fatal case of creosote poisoning. Postgrad Med f. 1984; 60(705):499-500. DOI: 10.1136/pgmj.60.705.499

13. Butzke C.E., Evans T.J., Ebeler S.E. Detection of Cork Taint in Wine Using Automated Solid-Phase MicroExtraction in Combination with GC/MS-SIM. ACS Symposium Series. 1998; 714:208-216. DOI: 10.1021/bk-1998-0714.ch015.

14. Dixon Mann J. Forensic Medicine and Toxicology. CHIZINE PUBN, 2018. 688 p. 
15. Guaiacol MSDS. Material Safety Data Sheet. URL: www.sciencelab.com/msds.php?msdsId=9924208.
16. Guaiacol.

PubChem.

URL:

https://pubchem.ncbi.nlm.nih.gov/compound/guaiaco l\#section=Top.

Поступила в редакцию 03.05.2019

Подписана в печать 20.06.2019

Для цитирования: Останин М.А., Чернова А.П., Шорманов В.К., Елизарова М.К. Применение классических методов для изолирования 2-метоксигидроксибензола (гваякола) из биологического материала. Курский научно-практический вестник «Человек и его здоровье». 2019;(2):102-110. DOI: 10.21626/vestnik/2019-2/12.

\title{
APPLICATION OF CLASSICAL METHODSFOR ISOLATING 2-METHOXYHYDROXYBENZENE (GUAIACOL) FROM BIOLOGICAL MATERIALS
}

\author{
๑) Ostanin M.A. ${ }^{1}$, Chernova A.P. ${ }^{2}$, Shormanov V.K. ${ }^{1}$ Elizarova M.K. ${ }^{3}$ \\ ${ }^{1}$ Kursk State Medical University (KSMU) \\ 3, K. Marx St., Kursk, Kursk region, 305041, Russian Federation \\ ${ }^{2}$ Institute of Natural Resources of Tomsk Polytechnic University (INR TPU) \\ 30, Lenin Avenue, Tomsk, Tomsk region, 634050, Russian Federation \\ ${ }^{3}$ Yeysk Medical College (YMC) \\ 74/2, Krasnaya St., Yeysk, Krasnodar Krai, 353680, Russian Federation
}

\begin{abstract}
Objective: the study of the features of isolating guaiacol from a biological material by classical methods.
Materials and methods. The object of the study is 2-methoxyhydroxybenzene (guaiacol) ("Fluka" company), containing $\geq 98 \%$ of the main substance. Models of biological matrices for the preparation of artificial mixtures with guaiacol are liver tissue and kidney. Liquid-liquid extraction is considered as the main purification method. TLC, UV spectrophotometry and HPLC are used for identification. Evaluation of the quantitative content of 2-methoxyhydroxybenzene in the extracts was carried out by the method of UV-spectrophotometry.

Results. This study was conducted on the comparative isolation of 2-methoxyhydroxybenzene (guaiacol) from biological materials by a number of classical methods: Stas-Otto's, A.A. Vasilyeva's, V.F. Kramarenko's and P. Valov's methods. The TLC, UV spectrophotometry and HPLC were used to identify the isolated analyte. Quantitative assessment of the isolated compound was performed by the method of spectrophotometry in the UV region (analytical wavelength $277 \mathrm{~nm}$ ). A modified version of the A.A. Vasilyeva's method was devised. It provided an additional stage of extraction purification of the isolated analyte consisting of the following: transformation of guaiacol as an ionized form from the chloroform extract into a water-alkaline solution ( $\mathrm{pH} 12.5-13$ ), acidification of the water-alkaline extraction with hydrochloric acid to $\mathrm{pH} 2-3$ and extraction of the resulting molecular form of guaiacol into a layer of ethyl acetate.

Conclusion. Based on the modified A.A. Vasilyeva's method, a protocol for determining guaiacol in the tissues of cadaveric organs was developed. When the content of guaiacol in the biomaterial is $0.01-0.2 \%$, this protocol allows to analyze (33.99-34.62) $\pm(5.84-7.35) \%$ of the analyte in liver tissues and (34.87-35.73) $\pm(5.66-6.97) \%$ in kidney tissues.

Keywords: 2-methoxyhydroxybenzene (guaiacol), classical isolation methods, modification of the A.A. Vasilyeva's method, detection in biomaterial, chemical-toxicological analysis.
\end{abstract}

Ostanin Maxim A. - Correspondence Postgraduate Student of Department of Pharmaceutical, Toxicological and Analytical Chemistry, KSMU, Kursk, Russian Federation. ORCID iD: 0000-0003-1984-5663. E-mail: m.a.ostanin@mail.ru

Chernova Anna P. - PhD in Chemistry, Associate Professor of Department of Physical and Analytical Chemistry, INR TPU, Tomsk, Russian Federation. ORCID iD: 0000-0001-7002-492X. E-mail: apa2004@mail.ru

Shormanov Vladimir K. - Doctor in Pharmacy, Professor of Department of Pharmaceutical, Toxicological and Analytical Chemistry, KSMU, Kursk, Russian Federation. ORCID iD: 0000-0001-8872-0691. E-mail: R-WLADIMIR@yandex.ru (correspondence author)

Elizarova Madina K. - PhD in Pharmacy, Lecturer, YMC, Yeysk, Russian Federation. ORCID iD: 0000-0002-8944-4358. E-mail: goukkemk@mail.ru

\section{CONFLICT OF INTEREST}

The authors declare the absence of obvious and potential conflicts of interest related to the publication of this article.

\section{SOURCE OF FINANCING}

The authors state that there is no funding for the study.

\section{CONFORMITY WITH THE PRINCIPLES OF ETHICS}

The study protocol was approved by the Regional Ethical Committee under Kursk State Medical University (Protocol No. 4 of 20.04.2018).

For citation: Ostanin M.A., Chernova A.P., Shormanov V.K., Elizarova M.K. Application of classical methodsfor isolating 2-methoxyhydroxybenzene (guaiacol) from biological materials. Kursk Scientific and Practical Bulletin "Man and His Health". 2019; (2):102110. DOI: $10.21626 /$ vestnik/2019-2/12. 